\title{
PERTUMBUHAN STEK PUCUK JABON PUTIH (Anthocephalus cadamba (Roxb.) Miq.) DENGAN PERENDAMAN MENGGUNAKAN EKSTRAK KECAMBAH KACANG HIJAU (Vigna radiata)
}

\author{
Nurul Huda ${ }^{1}$, Mukarlina ${ }^{1}$, Elvi Rusmiyanto Pancaning Wardoyo 1 \\ ${ }^{1}$ Program Studi Biologi, Fakultas MIPA, Universitas Tanjungpura, \\ Prof. Dr. H. Hadari Nawawi, Pontianak, 78124 \\ email korespondensi: hudanurul2412@gmail.com
}

\begin{abstract}
White jabon (Anthocephalus cadamba (Roxb.) Miq) are plants with high economic value. It can be propagated vegetatively using its shoot cuttings. One of the way to enhance the growth of shoot cuttings by submersion in green bean sprout extract was expected to produce shoot cuttings with better growth. This study aimed to determine the submersion effect of white jabon (A. cadamba) shoot cuttings in green bean (Vigna sinensis) sprout extract. The Completely Randomized Design (CRD) consisted of 5 levels of treatment were used. The cuttings were submerged in extract concentrations of $0 \%, 25 \%, 50 \%, 75 \%$, and $100 \%$. The study parameters of number of roots and leaves, plant height, wet and dry weight were observed. The results showed that the concentration treatment with $75 \%$ green bean sprout extract produced $9,25 \pm 2,50$ root strands, $5,75 \pm 0,50$ leaves, plant height of $20,13 \pm 1,11 \mathrm{~cm}$, wet weight of $12,39 \pm 3,62 \mathrm{~g}$, and dry weight of $1,51 \pm 0,42 \mathrm{~g}$.
\end{abstract}

Keywords: white jabon, green bean sprout extract, shoot cuttings, Anthocephalus cadamba

\section{PENDAHULUAN}

Kebutuhan kayu yang berasal dari hutan alam atau hutan produksi mengalami peningkatan. Seiring dengan meningkatnya jumlah penduduk kebutuhan bahan baku kayu industri di Kalimantan Barat semakin hari juga semakin meningkat. Menurut Haryo (2009), Kalimantan Barat mengalami kekurangan kayu industri sebanyak 2 juta $\mathrm{m}^{3}$ bahan baku setiap tahun. Salah satu alternatif dalam memenuhi kebutuhan bahan baku industri membuat pengusaha industri kayu mulai beralih pada kayu hasil budidaya.

Tanaman jabon putih merupakan salah satu tanaman kayu hasil budidaya asli Indonesia (Mindawati et al., 2015). Jabon termasuk salah satu jenis pohon yang dikembangkan pada hutan milik negara atau hutan rakyat karena memiliki beberapa kelebihan diantaranya masa pertumbuhannya yang cepat dan kualitas kayu yang baik, sehingga dapat dimanfaatkan sebagai bahan baku kayu perkakas, kayu bakar, kayu lapis, papan partikel, dan kertas (Putra et al., 2014). Perbanyakan tanaman jabon putih dapat dilakukan secara vegetatif dan generatif. Perkembangbiakan secara generatif berasal dari penyemaian biji. Akan tetapi, perkembangbiakan jabon putih secara generatif memiliki kekurangan karena harus menunggu pohon jabon putih berbuah (Saputra et al., 2011). Kekurangan lain dari pembiakan generatif adalah viabilitas benihnya yang cenderung menurun. Benih jabon yang telah disimpan kurang dari tiga bulan akan mengalami penurunan viabilitas mencapai 60-70\% (Mulyana \& Tuheteru, 2010).

Tanaman jabon putih (A. cadamba) dapat dikembangbiakan secara vegetatif salah satunya dengan cara stek pucuk. Menurut Suartini (2006), stek pucuk merupakan salah satu teknik pembiakan secara vegetatif yang dapat dilakukan pada berbagai jenis tanaman. Perkembangbiakan secara vegetatif memiliki keuntungan yaitu dapat memperoleh bibit yang banyak dalam waktu yang singkat (Mashudi \& Adinugraha, 2015). Namun, perbanyakan secara stek memiliki kekurangan yaitu pada proses pembentukan akar. Menurut Marendi (2015), pembiakan dengan metode stek ini memiliki kendala yaitu akar yang sulit tumbuh. Salah satu faktor yang mendukung keberhasilan dari pertumbuhan akar stek adalah dengan 
penambahan zat pengatur tumbuh (zpt). Zat pengatur tumbuh merupakan zat yang dapat memacu pertumbuhan tanaman dengan cara meningkatkan kemampuan berakar dan mempercepat proses pembungaan (Febriana, 2009). Menurut Yasman \& Smith (1988), untuk mempercepat pertumbuhan akar diperlukan perlakuan khusus dengan cara pemberian zat pengatur tumbuh eksogen.

Penelitian mengenai penggunaan ekstrak kecambah kacang hijau terhadap pertumbuhan stek pucuk jabon putih ( $A$. cadamba) belum pernah dilakukan. Belum adanya penelitian tentang penggunaan ekstrak kecambah kacang hijau sebagai zpt alami terhadap pertumbuhan stek pucuk jabon putih (A. cadamba) menjadikan penelitian ini penting untuk dilakukan.

\section{BAHAN DAN METODE}

\section{Waktu dan Tempat Penelitian}

Penelitian dilaksanakan selama 3 bulan dari bulan September sampai dengan November 2018 di Laboratorium Biologi Jurusan Biologi Fakultas Matematika Dan Ilmu Pengetahuan Alam Universitas Tanjungpura Pontianak.

\section{Bahan}

Bahan yang digunakan dalam penelitian ini yaitu pucuk tanaman jabon putih, akuades, pupuk kandang, tanah bakar dan kecambah kacang hijau

\section{Rancangan Percobaan}

Penelitian ini menggunakan Rancangan Acak Lengkap (RAL) yang terdiri dari 5 taraf perlakuan yaitu $\mathrm{P}_{0}(0), \mathrm{P}_{1}(25), \mathrm{P}_{2}(50), \mathrm{P}_{3}(75)$ dan $\mathrm{P}_{4}(100 \%)$. Masing-masing perlakuan dilakukan sebanyak 4 ulangan sehingga diperoleh 20 unit percobaan.

\section{Prosedur Kerja}

\section{Persiapan Media Tanam}

Persiapan media tanam menggunakan tanah bakar yang telah ditimbang sebanyak $1 \mathrm{~kg}$ kemudian dicampur dengan pupuk kandang dengan perbandingan 1:1. Campuran tanah dan pupuk kandang dibiarkan selama 2 hari.

\section{Pengambilan Stek Pucuk}

Bahan tanaman stek diambil dari tunas apikal dengan panjang stek antara 8-11 cm. Daun jabon putih yang disisakan sebanyak 3 helai, lalu masing-masing daun digunting setengah bagian.
Kemudian ujung bahan stek dipotong miring agar memperluas penyerapan air.

\section{Pembuatan Ekstrak Kecambah Kacang Hijau}

Kecambah kacang hijau yang berumur 3 hari dihaluskan dengan blender dan ditambah air secukupnya kemudian disaring menggunakan kain saring. Larutan ini dijadikan stok dengan konsentrasi $100 \%$. Perlakuan konsentrasi kecambah kacang hijau yang diperlukan dibuat dengan mengencerkan larutan stok ekstrak kecambah kacang hijau.

\section{Perendaman Bahan Stek}

Bahan stek jabon putih direndam ke dalam wadah yang telah berisi ekstrak kecambah kacang hijau dengan konsentrasi yang telah ditentukan. Waktu perendaman dilakukan selama 15 menit. Waktu perendaman berdasarkan uji pendahuluan.

\section{Penanaman}

Stek yang telah direndam dalam ekstrak kecambah kacang hijau kemudian ditanam dalam polibag yang telah diisi media dengan $1 / 3$ bagian stek yang dimasukkan ke dalam tanah. Stek ditanam dalam posisi tegak dan ditutup menggunakan plastik tranparan selama 1 minggu.

\section{Pemeliharaan Tanaman}

Pemeliharaan tanaman meliputi penyiangan dan penyiraman. Penyiraman dilakukan sebanyak 2 kali sehari yaitu pada pagi hari pukul $08.00-10.00$ WIB dan sore hari pukul 16.00-17.00 WIB. Penyiangan gulma dilakukan dengan cara mencabut gulma yang tumbuh di sekitar stek.

\section{Pengukuran Faktor Lingkungan}

Pengukuran faktor lingkungan meliputi pengukuran suhu tanah yang dilakukan setiap minggu menggunakan hygrometer, dan suhu udara menggunakan thermometer. Pengukuran analisi kandungan tanah meliputi C-organik, nitrogen $(\mathrm{N})$, posfor $(\mathrm{F})$, kalium $(\mathrm{K})$, dan pengukuran $\mathrm{pH}$ tanah menggunakan soil tester dilakukan sebelum tanam.

\section{Parameter \\ Pengukuran parameter dilakukan pada akhir penelitian yaitu 3 bulan setelah tanam. Parameter pertumbuhan yang diukur meliputi jumlah akar (helai), jumlah daun (helai), tinggi tanaman $(\mathrm{cm})$, berat basah (gram) dan berat kering (gram).}




\section{Analisis Data}

Data pertumbuhan stek dianalisis dengan ANOVA pada taraf uji $5 \%$. Bila terdapat pengaruh nyata dilanjutkan dengan uji Duncan pada taraf uji 5\%.

\section{HASIL DAN PEMBAHASAN}

\section{Hasil}

Berdasarkan hasil nilai rerata menunjukkan bahwa perendaman dengan menggunakan ekstrak kecambah kacang hijau pada stek pucuk jabon putih (A. cadamba) terjadi peningkatan nilai pada 5 variabel parameter pengamatan yaitu jumlah akar, jumlah daun, tinggi tanaman, berat basah dan berat kering. Namun, berdasarkan hasil analisis statistik pada penelitian ini tidak berpengaruh nyata terhadap tinggi tanaman $(\mathrm{F}=1,351, \mathrm{p}=$ 0,297; ANOVA), jumlah daun $(\mathrm{F}=0,091, \mathrm{p}=$ 0,984; ANOVA), jumlah akar $(\mathrm{F}=0,030, \mathrm{p}=$ 0,522 ; ANOVA), berat basah $(\mathrm{F}=1,489, \mathrm{p}=$ 0,255; ANOVA) dan berat kering $(\mathrm{F}=2,167, \mathrm{p}=$ 0,123 ; ANOVA).

Tabel 1. Rerata Jumlah Akar, Jumlah Daun, Dan Tinggi Tanaman Stek Pucuk Jabon Putih (A. cadamba) 60 hari stelah tanam

\begin{tabular}{cccc}
\hline Konsentrasi (\%) & $\begin{array}{c}\text { Jumlah } \\
\text { akar } \\
\text { (helai) }\end{array}$ & $\begin{array}{c}\text { Jumlah daun } \\
\text { (helai) }\end{array}$ & $\begin{array}{c}\text { Tinggi } \\
\text { Tanaman } \\
(\mathrm{cm})\end{array}$ \\
\hline Kontrol (0\%) & $6,75 \pm 0,96^{\mathrm{a}}$ & $5,50 \pm 1,00^{\mathrm{a}}$ & $17,1 \pm 1,37^{\mathrm{a}}$ \\
$25 \%$ & $8,50 \pm 1,29^{\mathrm{a}}$ & $5,25 \pm 0,96^{\mathrm{a}}$ & $19,75 \pm 3,30^{\mathrm{a}}$ \\
$50 \%$ & $8,50 \pm 0,50^{\mathrm{a}}$ & $5,50 \pm 1,92^{\mathrm{a}}$ & $17,73 \pm 2,26^{\mathrm{a}}$ \\
$75 \%$ & $\mathbf{9 , 2 5} \pm \mathbf{2 , 5 0} \mathbf{0}^{\mathrm{a}}$ & $\mathbf{5 , 7 5} \pm \mathbf{0 , 5 0}$ & $\mathbf{2 0 , 1 3} \pm \mathbf{1 , 1 1}^{\mathrm{a}}$ \\
$100 \%$ & $7,50 \pm 0,82^{\text {a }}$ & $5,50 \pm 1,00^{\mathrm{a}}$ & $19,43 \pm 2,67^{\mathrm{a}}$ \\
\hline
\end{tabular}

Keterangan: Angka yang diikuti oleh huruf yang sama berarti tidak berbeda nyata pada taraf 5\% berdasarkan uji Duncan

Hasil dari pertumbuhan stek pucuk jabon putih dengan perendaman ekstrak kecambah kacang hijau menunjukkan bahwa terjadi perubahan yang signifikan pada parameter jumlah akar dan tinggi tanaman. Namun pada jumlah daun tidak terlihat peningkatan yang signifikan. Jumlah akar menunjukkan bahwa pemberian ekstrak kecambah kacang hijau pada konsentrasi 0\% lebih rendah dibandingkan dengan konsentrasi lainnya. Jumlah akar $25 \%$ dan $50 \%$ memiliki hasil yang sama yaitu 8,50 helai. Jumlah akar tertinggi diperoleh pada konsentrasi $75 \%$ dengan nilai 9,25 helai. Tinggi tanaman mengalami peningkatan yang signifikan pada konsentrasi kontrol dan $75 \%$. Tinggi tanaman tertinggi diperoleh pada konsentrasi $75 \%$ dengan nilai $20,13 \mathrm{~cm}$ dan tinggi tanaman terendah diperoleh pada konsentrasi kontrol $(0 \%)$ dengan nilai $17,1 \mathrm{~cm}$. Jumlah daun pada semua konsentrasi tidak mengalami peningkatan yang signfikan. Konsentrasi 0 (kontrol), 50, dan 100\% memiliki rerata hasil yang sama yaitu 5,50 helai. Jumlah daun tertinggi diperoleh pada konsentrasi $75 \%$ dengan nilai 5,75 helai.

Tabel 2. Rerata Berat Basah Dan Berat Kering Tanaman Stek Pucuk Jabon Putih ( $A$. cadamba) 60 Hari Setelah Tanam

\begin{tabular}{|c|c|c|}
\hline $\begin{array}{c}\text { Konsentrasi } \\
(\%)\end{array}$ & $\begin{array}{c}\text { Berat basah } \\
\text { (gram) }\end{array}$ & $\begin{array}{l}\text { Berat Kering } \\
\text { (gram) }\end{array}$ \\
\hline Kontrol (0\%) & $10,02 \pm 1,82^{\mathrm{a}}$ & $1,39 \pm 0.28^{\mathrm{a}}$ \\
\hline $25 \%$ & $11,77 \pm 2,75^{\mathrm{a}}$ & $1,50 \pm 0,23^{\mathrm{a}}$ \\
\hline $50 \%$ & $8,79 \pm 3,75^{\mathrm{a}}$ & $1,08 \pm 0,45^{\mathrm{a}}$ \\
\hline $75 \%$ & $12,39 \pm 3,62^{\mathrm{a}}$ & $1,51 \pm 0,42^{\mathrm{a}}$ \\
\hline $100 \%$ & $8,38 \pm 2,05^{\mathrm{a}}$ & $0,98 \pm 0,19^{\mathrm{a}}$ \\
\hline
\end{tabular}

Keterangan: Angka yang diikuti oleh huruf yang sama berarti tidak berbeda nyata pada taraf 5\% berdasarkan uji Duncan

Berat basah menunjukkan bahwa perendaman menggunakan ekstrak kecambah kacang hijau ada konsentrasi $50 \%$ lebih rendah dibandingkan dengan $0 \%$ (kontrol). Berat kering pada konsentrasi $100 \%$ lebih rendah dibandingkan dengan $0 \%$ (kontrol). Berat basah dan berat kering tertinggi diperoleh pada konsentrasi $75 \%$ yaitu dengan nilai 12,39 dan 1,51 gram.

Perendaman stek pucuk jabon putih (A. cadamba) dalam ekstrak kecambah kacang hijau 75\% mengalami peningkatan untuk semua parameter penelitian yaitu jumlah akar, jumlah daun,tinggi tanaman, berat basah dan berat kering (Tabel 1). Perendaman stek pucuk jabon putih (A. cadamba) dalam ekstrak kecambah kacang hijau 100\% dapat menurunkan nilai pertumbuhan untuk semua parameter pengamatan.

\section{Pembahasan}

Hasil penelitian stek pucuk jabon (A. cadamba) tanpa perlakuan perendaman ekstrak kecambah kacang hijau menunjukkan hasil lebih rendah dibandingkan dengan konsentrasi lainnya. Kondisi ini disebabkan zpt endogen pada stek belum mampu memacu pertumbuhan stek pucuk jabon putih. Novianti \& Muswita (2013), menyatakan rendahnya pertumbuhan stek tanpa penambahan zpt belum mampu memacu pertumbuhan organ pada stek. Masa awal pertumbuhan stek 
memerlukan tambahan zpt dari luar untuk merangsang pertumbuhannya, sehingga dengan penambahan zpt eksogen akan meningkatkan kandungan zpt endogen dalam jaringan. Hal ini sesuai dengan hasil penelitian Sera, (2017) konsentrasi ekstrak bawang merah $1,5 \%$ paling efektif menghasilkan pertumbuhan stek batang nyawai (Ficus variegata Blume).

Perlakuan stek pucuk jabon putih dengan perendaman menggunakan ekstrak kecambah kacang hijau mengalami peningkatan yang si-gnifikan pada parameter jumlah akar. Perendaman ekstrak kecambah kacang hijau dengan konsentrasi 75\% hasilnya lebih tinggi di-bandingkan dengan konsentrasi lainnya yaitu 9,25 helai (Tabel 1). Hal ini disebabkan kandungan zpt di dalam ekstrak kecambah kacang hijau dengan konsentrasi 75\% memacu pembentukkan akar pada stek jabon putih. Menurut Mangoendidjojo (2003), penambahan auksin ekso-gen akan meningkatkan kandungan auksin en-dogen sehingga mampu memacu pembelahan sel yang kemudian berdiferensiasi membentuk akar. Penelitian Widiana et al. (2016) mengenai stek pucuk jabon dengan penambahan urin kambing menunjukkan hasil yang berbeda untuk jumlah akar. Hasil terbaik diperoleh konsentrasi urin kambing 12\%. Hal ini disebabkan urin kambing mengandung unsur hara NPK yang tidak dimiliki oleh kecambah kacang hijau sehingga dengan konsentrasi rendah mampu meningkatkan pertum-buhan akar.

Kecambah kacang hijau mengandung hormon auksin dan sitokinin yang dapat membantu pembentukkan organ stek. Hormon auksin dan sitokinin membantu pertumbuhan akar dengan cara merangsang pertumbuhan akar adventif, yaitu akar yang tumbuh dari stek. Sitokinin mampu merangsang pembentukan rambut-rambut akar sehingga mampu menyerap lebih banyak unsur hara dan air dari media tanam, sedangkan auksin merangsang kambium untuk membentuk xilem dan floem. Unsur hara dan air yang telah diangkut dapat digunakan untuk proses fotosintesis (Harahap, 2012). Auksin dapat meningkatkan bahan organik dari daun ke seluruh organ tumbuhan sehingga dapat mendorong pembentukan akar (Rahmadani et al., 2017).

Pertumbuhan tinggi tanaman dipengaruhi oleh hormon giberelin. Tinggi tanaman pada penelitian ini mengalami peningkatan yang signifikan. Hal ini sejalan dengan pembelahan dan pemanjangan sel. Perlakuan terbaik ditunjukkan pada konsentrasi ekstrak kecambah kacang hijau $75 \%$ yaitu 20,13 $\mathrm{cm}$ (Tabel 1). Peningkatan tinggi tanaman diduga karena adanya hormon giberelin yang terdapat pada ekstrak kecambah kacang hijau. Giberelin dapat merangsang pertumbuhan batang tanaman sehingga memicu petumbuhan tinggi tanaman. Setiawan \& Wahyudi, (2014) menyatakan di dalam batang, giberelin berfungsi menstimulasi pemanjangan sel dan pembelahan sel. Semakin tinggi tanaman maka semakin bertambah nodus tempat tumbuhnya daun. Jumlah daun terbaik ditunjukkan pada konsentrasi ekstrak kecambah kacang hijau 75\% yaitu 5,75 helai (Tabel 1). Auksin dalam tanaman akan membantu memacu giberelin dalam pemanjangan ruas-ruas batang sehingga menyebabkan peningkatan jumlah nodus pada tunas batang dan selanjutnya terjadi penambahan jumlah daun (Salisbury \& Ross, 1995).

Auksin dapat membantu merangsang atau menghambat pertumbuhan stek tergantung konsentrasi auksin yang diberikan. Auksin yang diberikan dalam jumlah yang sesuai dapat membantu merangsang pertumbuhan tanaman stek melalui pemanjangan dan pembelahan sel secara optimal. Namun, auksin yang diberikan dalam jumlah yang tidak sesuai untuk tanaman stek dapat menghambat pertumbuhan tanaman stek tersebut. Hal ini dapat dilihat dari hasil penelitian tidak mengalami peningkatan pada tinggi tanaman, berat basah dan berat kering tanaman jabon putih dengan pemberian ekstrak kecambah kacang hijau dengan konsentrasi 100\%. Penelitian Putra et al. (2014) juga menunjukkan hal serupa dimana pemberian Rootone-F dengan konsentrasi tertinggi 300 ppm pada stek pucuk jabon putih mengakibatkan persentase hidup, pertumbuhan panjang tunas, pertumbuhan diameter batang, panjang akar, dan jumlah daun tidak mengalami peningkatan. Menurut Wahidah \& Hasrul (2017), konsentrasi auksin yang terlalu berlebihan pada tanaman dapat memacu gas etilen yang kemudian dapat menghambat pemanjangan sel batang, menghambat pertumbuhan dan perkembangan daun serta batang.

Perlakuan berat basah dan berat kering terbaik ditunjukkan pada ekstrak kecambah kacang hijau dengan konsentrasi $75 \%$ yaitu berat basah 12,39 gram dan berat kering 1,51 gram (Tabel 2). Penambahan berat basah dan berat kering tanaman 
sejalan dengan pertambahan tinggi tanaman, jumlah akar, dan jumlah daun. Hal ini disebabkan karena pemberian ekstrak kecambah kacang hijau mampu merangsang perakaran sehingga akar dapat menyerap air dan hara. Peningkatan berat kering dipengaruhi oleh jumlah daun yang memiliki fungsi sebagai tempat terjadinya proses respirasi dan fotosintesis. Menurut Lakitan (2006), proses fotosintesis yang baik mampu meningkatkan kandungan senyawa organik dalam tanaman sehingga berat kering dalam tanaman tersebut meningkat.

Faktor lingkungan sangat mendukung proses pertumbuhan vegetatif tanaman. Suhu udara saat penelitian berkisar antara $26,2{ }^{\circ} \mathrm{C}-35,4{ }^{\circ} \mathrm{C}$. Kelembaban udara saat penelitian berkisar antara 53\%-96\% yang cukup baik untuk pertumbuhan stek pucuk jabon putih (A. cadamba). Menurut Lakitan (2006), suhu udara yang dapat mendukung per-tumbuhan stek berkisar antara $28{ }^{\circ} \mathrm{C}-36{ }^{\circ} \mathrm{C}$ dan kelembaban udara yang baik untuk pertumbuhan stek yaitu berkisar antara 50\%-80\%. Pada penelitian ini nilai $\mathrm{pH}$ tanah sebesar 6,5. Hal ini sesuai dengan penelitian Widiana et al (2016), menyatakan bahwa tanaman jabon putih dapat tumbuh pada $\mathrm{pH}$ tanah antara 4,5-7,5.

\section{DAFTAR PUSTAKA}

Febriana, S, 2009, Pengaruh Konsentrasi Zat Pengatur Tumbuh Dan Panjang Stek Terhadap Pembentukan Akar Dan Tunas Pada Stek Avokad (Persea americana Mill.), Skripsi, Fakultas Pertanian Institut Pertanian Bogor. Bogor

Harahap, F, 2012, Fisiologi Tumbuhan : Suatu Pengantar, Unimed Press, Medan

Haryo, 2009, Industri Kayu Kalbar Kekurangan 2 Juta $m^{3}$ Bahan Baku. Diakses pada 23 Agustus 20017 https://amp-kompas-com.cdn.ampproject.org

Lakitan, B, 2006, Dasar-Dasar Fisiologi Tumbuhan, Raja Grafindo Perkasa, Jakarta

Mangoendidjojo, 2003, Dasar-Dasar Pemuliaan Tanaman, Kanisius, Yogyakarta

Marendi, YA, 2015, Pembiakan Vegetatif Stek Pucuk Benuang Laki (Duabanga moluccana Blume) Pada Berbagai Konsentrasi Hormon Tumbuh Dan Media, Skripsi, Departemen Silvikultur,
Fakuktas Kehutanan, Institute Pertanian Bogor, Bogor

Mashudi, \& Adinugraha, HA, 2015, Kemampuan Tumbuh Stek Pucuk Pulai Gading (Alstonia scholaris (L.) R. Br.) Dari Beberapa Posisi Bahan Stek Dan Model Pemotongan Stek, Jurnal Penelitian Kehutanan Wallacea, vol. 4, issue 1, hal. 63-69

Mindawati, N, Mansur, I, \& Setio, P, 2015, Bunga Rampai Teknologi Pembenihan dan Pembibitan Jabon Putih (Neolamarckia cadamba (Roxb.) Bosser), Forda Press, Bogor

Mulyana, I, \& Tuheteru, DF, 2010, Kayu Jabon, Penebar Swadaya, Jakarta

Novianti, R, \& Muswita, 2013, Pengaruh zat pengatur tumbuh terhadap pertumbuhan jeruk keprok (Citrus nobilis Lour) Var. Pulau Tengah, Jurnal Sains dan Matematika, vol. 6, no. 1, hal. 48-50

Putra, F, Indriyanto, \& Riniarti, M, 2014, Keberhasilan Stek Pucuk Jabon (Anthochepalus cadamba) Dengan Pemberian Beberapa Konsesntrasi Rootone-F, Jurnal Silva Lestari, vol. 2 no. 2 hal. $33-40$

Rahmadani, Mukarlina, \& Wardoyo, ERP, 2017, Pertumbuhan Stek Batang Melati Putih (Jasminum sambac (L) W. Ait) Setelah Direndam dengan Pupuk Organik Cair (POC) Tauge dan Bonggol Pisang, Protobiont, vol. 6, no. 1 , hal. $72-78$

Salisbury, F,B, \& Ross, C,W, 1995, Fisiologi Tumbuhan, Institut Teknologi Bandung, Bandung

Saputra, B, Winarni, E, \& Bakri, S, 2011, Pertumbuhan Stek Jabon (Anthocephalus cadamba Miq.) Dari Tiga Bagian Batang Dengan Sistem Koffko, Universitas Lambung Mangkurat Banjarbaru

Sera, AWN, 2017, Pengaruh Pemberian Rootone F, Urin Sapi, Kecambah Kacang Hijau (tauge) dan Bawang Merah Terhadap Keberhasilan Pertumbuhan Stek Batang Nyawai (Ficus Variegata Blume), Skripsi, Universitas Islam Negeri Sunan Kalijaga, Yogyakarta

Setiawan \& Wahyudi, A, 2014, Pengaruh Giberelin Terhadap Beberapa Varietas Lada Untuk Penyediaan Benih Secara Tepat, Balai Penelitian Tanaman Rempah Dan Obat, bogor, vol. 25, no. 2, hal. 111-118 
Protobiont (2019) Vol. 8 (3) : $28-33$

Suartini, S, 2006, Pengaruh dosis rootone-F terhadap pertumbuhan semai cabutan sentang (Melia excels Jack.), Skripsi, Fakultas Kehutanan, Institut Pertanian Bogor

Tiara, NZA, \& Chairul, 2017, Pengaruh Konsentrasi IBA Terhadap Kemampuan Berakar Stek Pucuk Alstonia scholaris (L.)R.Br. Sebagai Upaya Penyediaan Bibit Untuk Revegetasi, Metamorfosa, Journal of Biological Sciences, vol. 4, no. 1, hal. 29-34

Wahidah, FB \& Hasrul. 2017, Pengaruh Pemberian Zat Pengatur Tumbuh Indole Acetid Acid (IAA) Terhadap Pertumbuhan Tanaman Pisang Sayang (Musa paradisiaca L. Var. Sayang) Secara In Vitro, Jurnal Teknosains, vol. 11, no. 1, hal. 2741

Widiana, E, Linda, R, \& Mukarlina, 2016, Pertumbuhan Stek Pucuk Tanaman Jabon Puth (Anthocephalus cadamba (Roxb.) Miq.) Setelah Direndam Dalam Urin Kambing (Capra aegagrus), Protobiont, vol.5, no. 1, hal. 1-7

Yasman I, \& Smith WTM, 1988, Metode Pembuatan Stek Dipterocarpaceae, Balai Penelitian, Samarinda 